\title{
Enteropathogenic Escherichia coli and life threatening chronic diarrhoea
}

\author{
S M Hill, A D Phillips, J A Walker-Smith
}

\begin{abstract}
Enteropathogenic Escherichia coli (EPEC) infection is not generally thought to cause severe diarrhoea after the neonatal period. Patients admitted to Queen Elizabeth Hospital for Children over the three years (1984-7) with diarrhoea and EPEC infection were reviewed. Clinical details, features of small intestinal mucosa, and treatment were recorded in those who developed chronic diarrhoea with failure to thrive. Twenty six children with EPEC required hospital admission for diarrhoea and six of these (23\%) developed chronic diarrhoea. In contrast only two (5\%) of 42 with other serogroups of $E$ coli $(p<0.01)$ and $28(4 \%)$ of 764 children without EPEC admitted with acute diarrhoea developed chronic symptoms $(p<0.01)$. EPEC serogroups detected in the stool of the six children with chronic diarrhoea were 0128 in three, 0114 in two, and 0119 in one. The patients' clinical characteristics were: previous good health, no significant immunodeficiency, age 4-10 months, foreign travel (three of six), severe life threatening secretory diarrhoea from 0.5 to 1.51 per day (four of six), small intestinal enteropathy (five of six) three of whom showed mucosal adherent, non-invasive $E$ coli of the same serotype as that in the stool, in association with microvillous loss and pedestal formation. All were treated with hypoallergenic feeds, two with parenteral nutrition, and three with parenteral antibiotics. All eventually recovered. EPEC infection is a common treatable cause of life threatening chronic diarrhoea in infancy.
\end{abstract}

Escherichia coli that do not invade the mucosa or excrete heat labile or heat stable enterotoxins yet cause diarrhoea in volunteer studies ${ }^{1}$ have been termed enteropathogenic $E$ coli (EPEC). It is well recognised that these $E$ coli are associated with acute diarrhoea but it is not generally accepted that serious diarrhoea may occur with EPEC infection after the neonatal period. ${ }^{2}$ However, we have found EPEC in association with severe traveller's diarrhoea in four of six children in one study ${ }^{3}$ and in three of 10 in a second. ${ }^{4}$ Furthermore, we have noticed an improvement in symptoms with antibiotic treatment, ${ }^{5}$ which is not a generally accepted form of treatment for $E$ coli. $^{2}$

There is no readily available specific test for EPEC, although recent in vivo clinicopathological studies have shown a particular form of association of some EPEC strains with the brush border - that is microvillous effacement and pedestal formation..$^{6-8}$ It is not clear, however, whether all EPEC have this ability, and as there is no single reliable diagnostic test several approaches are currently used to recognise EPEC. These include O:H serotyping, ${ }^{9}$ the ability to produce the previously described lesion in vivo, ${ }^{6-8}$ or in vitro, ${ }^{1011}$ pattern of adherence on tissue culture cells, ${ }^{1213}$ and a DNA probe for an EPEC adherence factor (EAF) plasmid. ${ }^{1+}$ Most microbiology laboratories rely solely on conventional 0 serogrouping to classify EPEC as $\mathrm{H}$ antigen testing is expensive and, in common with the other tests, is not routinely available. Two classes of EPEC have been described in terms of their ability to show 'localised' adherence to tissue culture cells. ${ }^{14}$ is Those that show localised adherence are generally EAF positive. ${ }^{14}$ is However, EAF positivity is plasmid related, whereas the ability to cause the lesion is probably chromosomally determined. ${ }^{10}$ The association between EAF, adherence pattern, and the lesion has yet to be determined.

This study was performed retrospectively and EPEC were tested for by 0 serogrouping. Only bacteria with serogroups that have been shown to produce microvillous effacement and pedestal formation in vivo have been considered to be EPEC. These are $0125,{ }^{6} 0119,{ }^{7} 0111,{ }^{8} 0128,{ }^{16} 021$ and 0114 (unpublished observations).

The aims of the study were to:

(1) Determine the proportion of children presenting with acute EPEC infections who develop chronic diarrhoea.

(2) Compare this with the prevalence of chronic diarrhoea in children presenting with acute diarrhoea from other causes, including infections with other serogroups of $E$ coli.

(3) Look for any specific characteristics associated with EPEC infection and chronic diarrhoea. (4) Review the treatment of these patients.

\section{Patients and methods}

The total number of patients admitted to this hospital with acute gastroenteritis was determined over a three year period between 1984 and 1987. The number of children who developed chronic diarrhoea - that is diarrhoea which persisted for 14 days or more - and those who had a serogroupable $E$ coli in their stool were recorded.

In those with EPEC serogroups, age, sex, and ethnic origin were recorded, and those in whom diarrhoea lasted for more than two weeks, were looked at in greater detail. The additional in formation obtained included foreign travel, incidence of associated infections, premorbid health, recent antibiotic treatment, and history of atopy. Height and weight centiles were recorded as were immunological investigations including total white cell count and differential, serum immunoglobulin values, neutrophil mobility, yeast opsonisation, and phytohaemag- 
glutinin stimulation, if done. Stool cultures were repeated every day for the first five days of hospital admission and, if still positive, at least twice a week thereafter. Stool electron microscopy was performed on admission to hospital. These tests were repeated if diarrhoea worsened. Diarrhoea was considered to be secretory if the stool sodium concentration was over $80 \mathrm{mmol} / \mathrm{l}$, and likely to be osmotic if $1 \%$ (or over) reducing substances were present. Stool samples were tested for heat labile and heat stable enterotoxins at Colindale Public Health Laboratory, UK.

Proximal small intestinal mucosal biopsy was performed in all patients, with fully informed parental consent. Each biopsy specimen was routinely processed for light and electron microscopy and for dissacharidase assay. ${ }^{17}$ On electron microscopy, as well as looking at mucosal structure, the presence of organisms was sought. If bacteria were identified an indirect immunofluorescence technique was used to determine if they were $E$ coli of the same serotype as those detected in the stool. This involved incubating $5 \mu \mathrm{m}$ thick sections with the appropriate $E$ coli agglutinating antisera for 30 minutes at $37^{\circ} \mathrm{C}$, washing in phosphate buffered saline (PBS), applying fluorescein conjugated antirabbit antisera $\left(30\right.$ minutes at $37^{\circ} \mathrm{C}$ ), washing in PBS, and viewing in a Leitz indirect immunofluorescence microscope. Controls involved substituting PBS for the primary and secondary antisera and using an unrelated agglutinating antisera in place of the primary antisera.

Details of treatment reviewed included duration of treatment with intravenous fluids, use of parenteral nutrition and a hypoallergenic cows' milk-free diet. Antibiotic treatment, and any associated improvement in symptoms, were also recorded.

\section{Results}

During the three year period studied, 790 children were admitted with acute gastroenteritis. ' 0 ' serogroupable $E$ coli were detected in the stool of 68 children, and in 26 these were of EPEC serogroups. Altogether $28(3 \cdot 7 \%)$ of the 764 children without EPEC infections developed chronic diarrhoea. In contrast six (23\%) of the 26 with EPEC had chronic diarrhoea, and this difference is statistically significant, $p<0.01$ (see Table I). There was also a statistically significant difference $(\mathrm{p}<0.05)$ between the number with EPEC (six of 26) and the number with nonEPEC serogroups of $E$ coli (two of 42) who had chronic diarrhoea. The incidence in non-EPEC $E$ coli infections (one in 21) was similar to that in non- $E$ coli diarrhoea (one in 27). The two children with non-EPEC $E$ coli both had an 055 infection. One has been described previously as a case of traveller's diarrhoea. ${ }^{+} \mathrm{He}$ returned from Morocco at 9 months of age with diarrhoea. He had a concurrent rotavirus infection and a normal small intestinal biopsy specimen. The other child was aged 13 months, and partial villous atrophy was seen on small intestinal biopsy specimen for which no other cause was found. Both have recovered fully.

Children admitted with EPEC infection were
TABLE I Incidence of chronic diarrhoea requiring prolonged hospital admission in children admitted with acute diarrhoea and statistical differences between disease groups

\begin{tabular}{|c|c|c|}
\hline & $\begin{array}{l}\text { No with acute } \\
\text { diarrhoea } \\
\text { requiring hospital } \\
\text { admission }\end{array}$ & $\begin{array}{l}\text { No (\%) who developed } \\
\text { chronic diarrhoea } \\
\text { for which prolonged } \\
\text { hospital admission } \\
\text { was required }\end{array}$ \\
\hline $\begin{array}{l}\text { Group 1: } \\
\text { EPEC } \\
(021,0111,0114 \text {, } \\
0119,0125,0128)\end{array}$ & 26 & $6(23)$ \\
\hline $\begin{array}{l}\text { Group 2: } \\
\text { Non-EPEC } \\
\text { Escherichia coli }\end{array}$ & 42 & $2(5)$ \\
\hline $\begin{array}{l}\text { Group 3: } \\
\text { All Escherichia coli } \\
\text { (Groups } 1+2 \text { ) }\end{array}$ & 68 & $8(12)$ \\
\hline $\begin{array}{l}\text { Group 4: } \\
\text { All other admissions } \\
\text { for acute diarrhoea }\end{array}$ & 722 & $26(3 \cdot 4)$ \\
\hline $\begin{array}{l}\text { Total/all } \\
\text { patients with } \\
\text { acute diarrhoea }\end{array}$ & 790 & $34(4)$ \\
\hline
\end{tabular}

$\mathbf{x}^{2}$ test for significant differences:

Group 1 v $2 \mathrm{p}<0.05$

Group $1 v 4 \mathrm{p}<0.01$

Group $2 v 4 \mathrm{NS}$

Group $3 v 4 \mathrm{p}<0.01$

EPEC=enteropathogenic $E$ coli

aged 2 weeks to 10 years (mean 10 months). Apart from one boy of 10 years, all these children were under 4 years and $18(69 \%)$ were under 1 year. There were 18 boys and eight girls - a boy:girl ratio of $2 \cdot 25: 1$. If the 10 year old child is excluded, the average age for boys was $11 \cdot 3$ months (median 12 months), and for girls 8.6 months (median 7 months). Eleven children were white and 15 were UK born children of immigrants (nine originated from the Indian subcontinent).

The number of children infected with each $E$ coli serogroup was as follows: $0111, \mathrm{n}=4$; $0114, \mathrm{n}=5 ; 0119, \mathrm{n}=8 ; 0125, \mathrm{n}=3$; and 0128 , $\mathrm{n}=6$.

Six children with EPEC developed chronic diarrhoea and in all cases symptoms were severe and life threatening. They were all under 12 months old and their ages ranged from 4 to 10 months (median 7 months). This was not significantly different to the age at presentation of the other children. Four were boys and two girls. All six were born in this country, but five were of Asian origin and one was white European. Three of the six had recently travelled to the Indian subcontinent to stay in villages with relatives. In two of the three the diarrhoea had started there and had not responded to treatment with oral ampicillin. The third developed symptoms immediately upon his return. One child who had not been abroad became infected with an EPEC of the same serogroup as that isolated from the stool of relatives who had recently returned from India. The serogroups detected were 0128 in three patients, 0114 in two, and 0119 in one. One child with 0128 was also found to have serogroups 055 and 086 when stool samples were analysed at Colindale Public Health Laboratory. No heat labile or stable toxins were detected. Four of the six patients had copious secretory diarrhoea, passing from $500 \mathrm{ml}$ to $1500 \mathrm{ml}$ of watery stool (approximately $10-25 \%$ of body water) per 24 hours with a sodium content of 95 


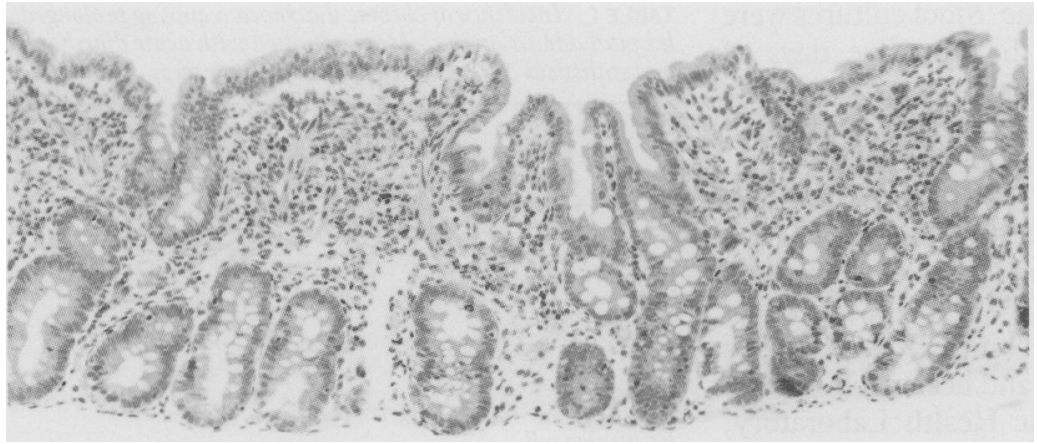

Figure 1: Proximal small intestinal mucosal biopsy specimen in patient 3 showing crypt hyperplastic villous atrophy with neutrophil infiltration. Original magnification $\times 215$.

Figure 2: Electron micrograph showing Escherichia coli 0114 adhesion with microvillous effacement and pedestal formation (patient 3). Original magnification $\times 15000$

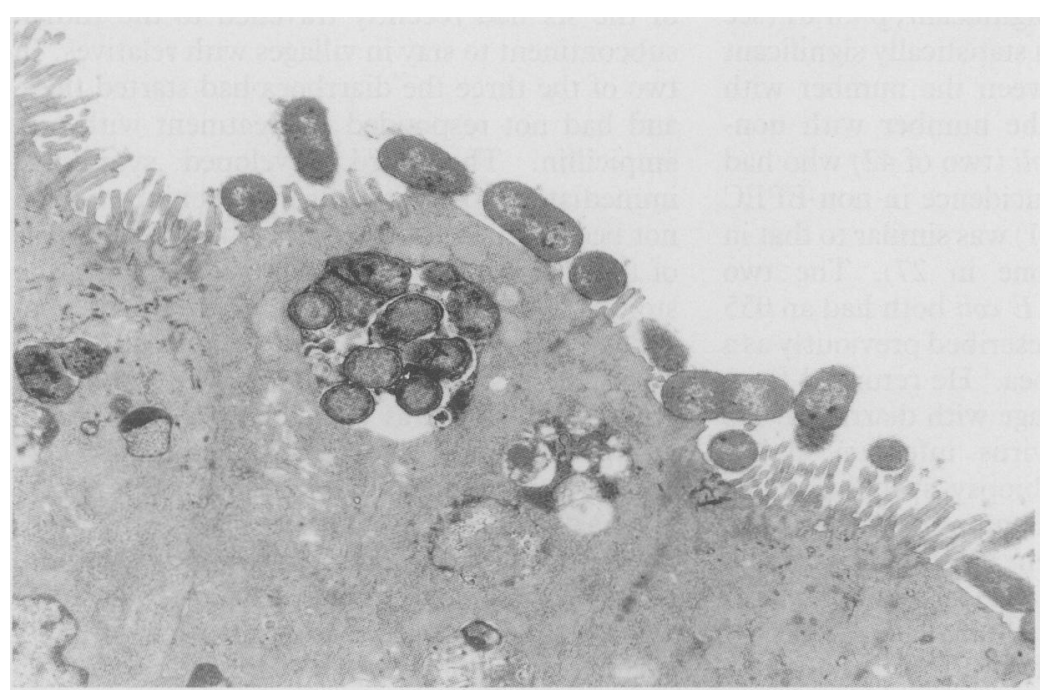

specimens were histologically abnormal in five patients. The sixth child, who was already improving clinically on a hypoallergenic feed showed a normal small intestinal mucosa without evidence of bacterial adherence on biopsy specimen. The abnormalities in the other five were a moderately severe villous atrophy and crypt hyperplasia (Fig 1). In three patients with secretory diarrhoea, electron microscopy showed adhering bacteria associated with microvillous effacement and pedestal formation (Fig 2). Immunofluorescent staining confirmed that the adherent bacteria were of the same EPEC serogroup as that in the stool. All children were treated with intravenous fluids for at least 48 hours after hospital admission while Dioralyte (Rorer Pharmaceuticals, UK. Composition sodium, $35 \mathrm{mmol} / \mathrm{l}$; potassium, $13.4 \mathrm{mmol} / \mathrm{l}$; chloride, $30.5 \mathrm{mmol} / \mathrm{l}$; lactate, $17.7 \mathrm{mmol} / \mathrm{l}$; and glucose, $200 \mathrm{mmol} / \mathrm{l}$ ) was gradually introduced.

All children were regraded onto hypoallergenic feeds, one to a whey hydrolysate (Alfaré, Nestle) and five to a casein hydrolysate (Pregestimil, Mead Johnson), but only two tolerated Pregestimil with symptomatic relief. The three children who did not tolerate Pregestimil had secretory diarrhoea, two had had adherent bacteria detected, none were clinically improving, and all had had diarrhoea for four to five weeks. In view of this, treatment with intravenous gentamicin was begun. Two were also given penicillin which was changed to piperacillin in the child who developed Klebsiella septicaemia. When she developed severe neutropenia this was changed to ceftazidine. One of these three children was severely unwell with hypovolaemic shock, and so received two doses of somatostatin 12 hours apart. Two of the children were also begun on parenteral nutrition (Table II).

Diarrhoea stopped dramatically in all three children within five days of beginning antibiotics, did not recur, and oral feeding was tolerated. Two of the children passed two or three small, loose stools per day, and the child who received somatostatin was constipated for three weeks from 24 hours after beginning antibiotics and somatostatin. EPEC were detected in the stool from the other two children for up to three weeks after starting antibiotics. Small intestinal biopsies have been repeated in three children, and were histologically normal without evidence of adhering bacteria. One was taken while the child was still on antibiotic treatment.

The children have, as far as possible, been followed up for up to two years since admission to hospital. All have remained healthy and thriving and have had no further hospital admissions with diarrhoea. One child has been lost to follow up. Three successfully returned to a normal diet by two years of age, but two remain on cows' milk free diets. One of the two is the child with severe eczema, and this is exacerbated if she ingests cows' milk.

\section{Discussion}

EPEC infection is a common finding in the stool of children presenting to this hospital with gastroenteritis and is significantly more commonly associated with serious chronic diarrhoea 
TABLE II Clinical features and treatment

\begin{tabular}{|c|c|c|c|c|c|}
\hline $\begin{array}{l}\text { Patient } \\
\text { No }\end{array}$ & $\begin{array}{l}\text { Age on } \\
\text { admission } \\
\text { (mths) }\end{array}$ & Travel & Diarrhoea & $\begin{array}{l}\text { Escherichia coli } \\
\text { serogroup }\end{array}$ & $\begin{array}{l}\text { Antibiotic and parenteral } \\
\text { nutrition }(T P N) \\
\text { treatment }\end{array}$ \\
\hline $\begin{array}{l}1 \\
2\end{array}$ & $\begin{array}{r}10 \\
7\end{array}$ & India & $\begin{array}{l}R \\
S\end{array}$ & $\begin{array}{l}0119 \\
0114(\mathrm{~A})\end{array}$ & $\begin{array}{l}\text { TPN } \\
\text { Gentamicin } \\
\text { Penicillin }\end{array}$ \\
\hline $\begin{array}{l}3 \\
4 \\
5\end{array}$ & $\begin{array}{l}9 \\
7 \\
5\end{array}$ & India & $\begin{array}{l}\text { S } \\
\mathbf{S} \\
\mathbf{R}\end{array}$ & $\begin{array}{l}0114(\mathrm{~A}) \\
0128(\mathrm{~A}) \\
0128\end{array}$ & Gentamicin \\
\hline 6 & 4 & Bangladesh & $\mathbf{S}, \mathbf{R}$ & 0128 & $\begin{array}{l}\text { TPN, gentamicin } \\
\text { penicillin } \\
\text { ceftazidime } \\
\text { piperacillin }\end{array}$ \\
\hline
\end{tabular}

$S=$ secretory; $R=>1 \%$ reducing substances in stool; $\mathrm{A}=$ adherent to small intestine. have been colonised; for example adherent EPEC have been detected in rectal mucosa.

The mainstay of treatment was initially rehydration and restoring electrolyte balance using intravenous fluids. These had to be carefully administered as electrolyte and water imbalance can easily occur particularly when an infant is passing between 10 and $25 \%$ of body water every 24 hours. Subsequent concomitant treatment was parenteral nutrition in two, antibiotics in three, somatostatin in one, and in all patients, a hypoallergenic diet.

Total parenteral nutrition is very expensive and is not readily available in the parts of the world where most of these children acquired their illness. It is possible that the two children who were given it would have died without its additional support. Hypoallergenic feeds are also too costly in many places, and may have been necessary treatment for all six patients.

Antibiotic treatment seemed to be life saving in three patients and this has been reported previously. ${ }^{5}$ These three children passed up to $1500 \mathrm{ml}$ per day of watery stool, even when taking nothing orally, and had had diarrhoea for four to five weeks. Within five days of beginning antibiotic treatment there was a dramatic symptomatic response. Although antibiotic use is viewed with caution in Western countries, ${ }^{2}$ a short course is frequently given in many parts of the world. This seems to have led to multiple antibiotic resistance ${ }^{18}$ so the antibiotic given is usually ineffective (as in two of our patients treated with ampicillin in India). We would, however, recommend the use of appropriate antibiotics in patients similar to those described in this paper.

The rationale for giving somatostatin was its effect on increasing intestinal salt and water absorption as shown in the normal ileum and in patients with secretory diarrhoea due to a variety of causes. ${ }^{19-22}$

The one child who was given somatostatin did not open his bowels for three weeks. However, he was also given antibiotics. Somatostatin treatment should be investigated by controlled trial before it can be considered effective, as the result in this child may have been purely a response to the antibiotics.

An interesting observation was the persistence of EPEC excretion in stool after clinical recovery, when antibiotic treatment had been given, as shown previously. ${ }^{23}$ Possibly an asymptomatic carrier state had developed like that seen in Salmonella infections. ${ }^{24}$

In conclusion, in most cases EPEC infection is associated with mild symptoms only, but these may become persistent and life threatening in previously healthy infants who seem to be immunocompetent. In our experience this is frequently associated with foreign travel to a developing country. Recovery seems to depend on intravenous rehydration and appropriate antibiotic treatment. Hypoallergenic feeds and parenteral nutrition may be required in some patients.

1 Levine MM, Bergquist EJ, Nalin Dr, et al. Escherichia coli strains that cause diarrhoea but do not produce heat labile or heat stable enterotoxins and are non-invasive. Lancet 1978; secondary to their poor nutritional state on presentation. small intestinal mucosa in three children with severe symptoms, in three they were not. As a small intestinal biopsy specimen only comprises about $30 \mathrm{~mm}$ of jejunal surface it is presumably possible to miss examples of adherence. Additionally, other regions of the intestinal tract may 
2 Gorbach SL. Bacterial diarrhoea and its treatment. Lancet 1987; ii: $1378-82$.

3 Hutchins $P$, Hindocha $P$, Phillips A, Walker-Smith JA Traveller's diarrhoea with a vengeance in children of UK Traveller's diarrhoea with a vengeance in children of UK 1982;3: 208-11.

4 Msengi AE, Phillips AD, Risdon RA, Walker-Smith JA Travellers diarrhoea among children returning to the United Kingdom from visits abroad. Ann Trop Paediatr 1988; 8 173-80

5 Hill SM, Phillips AD, Walker-Smith JA, Sanderson IR, Milla $P J$. Use of antibiotics in $E$ coli gastroenteritis. Lancet 1988; i: 771-2.

6 Ulshen MH, Rollo JL. Pathogenesis of Escherichia coli gastroenteritis in man - another mechanism. NEngl f Med 1980, 302: 99-101.

7 Rothbaum R, McAdams AJ, Giannella R, Partin JC. Clinicopathologic study of enterocyte-adherent Escherichia coli: a cause of protracted diarrhoea in infants. Gastroenterology 1982; 83: 441-54.

8 Taylor CJ, Hart A, Bat RM, McDougall C, Mclean L. Ultrastructural and biochemical changes in human jejunal mucosa associated with enteropathogenic Escherichia col (0111) infection. I Pediatr Gastroenterol Nutr 1986; 5: 70-3.

9 Levin MM, Edelman R. Enteropathogenic Escherichia coli of classic serotypes associated with infant diarrhoea: epidemiology and pathogenesis. Epidemiol Rev 1984; 6: 31-51.

10 Knutton S, Lloyd DR, McNeish AS. Adhesion of enteropathogenic $E$ coli to human intestinal enterocytes and cultured human intestinal mucosa. Infect Immun 1987; 69-77.

11 Knutton S, Baldwin T, Williams PH, McNeish AS. Actin accumulation at sites of bacterial adhesion to tissue culture cells: basis of a new diagnostic test for enteropathogenic and cells: basis of a new diagnostic test for enteropathogenic and enteroh

12 Cravioto A, Gross RJ, Scotland SM, Rowe B. An adhesive factor found in strains of Escherichia coli belonging to the traditional infantile enteropathogenic serotypes. Cur Microbiol, 1979; 3: 1057-60.

13 Mathewson JJ, Cravioto A. Hep-2 cell adherence as an assay for virulence among diarrheagenic Escherichia coli. $\mathcal{F}$ Infect Dis 1989; 159: 1057-60.

14 Nataro PJ, Baldini MM, Kaper JB, Black RE, Bravo N, Levin MM. Detection of an adherence factor of enteropathogenic Escherichia coli with a DNA probe. $\mathcal{F}$ Infect Dis 1985; 3: Escher 5 .

15 Levin MM, Nataro JP, Karch $H$, Baldini MM, et al. The diarrhoeal response of humans to some classic serotypes of encoding an enteroadhesiveness factor. F Infect Dis 1895; 3 . $550-9$.

16 Phillips AD. Small intestinal mucosa in childhood in health and disease. Scand $\mathcal{F}$ Gastroenterol 1981; 16 (suppl 70): 65-85.

17 Phillips AD, Avigad S, Sacks J, Rice SJ, France NE, WalkerSmith JA. Microvillous surface area in secondary disaccharidase deficiency, Gut 1980; $21: 44-8$.

18 Lacroix J, Delage G, Gosselin F, Chicoine L. Severe protracted diarrhoea due to multiresistant adherent Escherichio tracted diarrhoea due to multiresistant

19 Mulinhill S, Passaro E, Debas H, Yamaha T. Severe diarrhoea after colonic pseudo-obstruction: treatment with somatoafter colonic pseudo-obstruction: tr
statin. $N$ Engl $/$ Med $1984 ; 310: 467$.

20 Williams NS, Cooper JC, Axon ATR, King RF, Barker M Use of a long acting somatostatin analogue in controlling life threatening ileostomy diarrhoea. $\mathrm{Br} M e d \mathcal{F} 1984 ; 289$ 1027-8.

21 Nightindale JMD, Walker ER, Burnham WR, Farthing MJ Leonard Jones G. Octreotide (a somatostatin analogue) improves the quality of life in some patients with a short intestine. Aliment Pharmacol Ther 1986; 3: 367-73.

22 Ruskone A, Rene E, Chay Vialle JA, et al. Effect of somatostatin on diarrhoea and on small intestinal water and electrolyte transport in a patient with pancreatic cholera. $D i g$ Dis Sci 1982;27: 459-66.

23 Thoren A, Wolde-Manan T, Stinzing G, Wadstrom T, Hable $D$. Antibiotics in the treatment of gastroenteritis caused by enteropathogenic Escherichia coli. $\mathcal{F}$ Infect Dis 1980; 141: 27-31.

24 Booth IW, Candy DCA, McNeish AS. Acute infective diarrhoea and vomiting. In: Milla PJ, Muller DPR, ed. Harries Paediatric gastroenterology. Edinburgh: Churchill Livingstone 1988: $318-52$ 